\title{
TINDAK TUTUR MEMINTA MAAF SECARA SAMUDANA TERSELUBUNG DALAM BAHASA JAWA
}

Apologizing Speech Acts Through Samudana Indirectly in Javanese Language

\author{
Endang Sri Maruti \\ Dosen Prodi PGSD IKIP PGRI Madiun \\ Poe-el: endangsm@gmail.com
}

\begin{abstract}
Abstrak
Permintaan maaf lazimnya dilakukan seseorang jika melakukan kesalahan. Pada masyarakat tutur bahasa Jawa, meminta maaf cenderung dinyatakan terlebih dahulu meskipun sebenarnya hal yang dituturkan atau dilakukannya belum tentu salah. Fokus penelitian ini adalah bentuk tindak tutur meminta maaf pada masyarakat Jawa di wilayah Kelurahan Beringin, Kecamatan Lakarsantri, Kota Surabaya. Penelitian ini menggunakan pendekatan deskriptif kualitatif dengan rancangan etnopragmatik. Data penelitian diperoleh dari 46 subjek penelitian melalui observasi dan wawancara mendalam. Analisis data dilakukan dengan model alir yang di dalamnya terdapat reduksi, sajian, verifikasi, dan penyimpulan. Hasil penelitian menunjukkan bahwa bentuk tutur untuk meminta maaf dibedakan berdasarkan modus dan komponennya.

Kata Kunci: bentuk, tindak tutur meminta maaf, masyarakat Jawa
\end{abstract}

\begin{abstract}
Apology is typically done when someone made a mistake. In Javanese speech community, apologized tend declared first even though it is spoken or done is not necessarily wrong. This research focus on form of apology speech acts in the Javanese community in the Beringin Village, District Lakarsantri, Surabaya. To explain the focus, the researcher used descriptive-qualitative with ethnopragmtic design. Data are collected from 46 subjects by observation and indepth interviews. Data are analizd using Miles and Huberman's flow model covering three steps: reduction, display, and verivication/concluison. The results showed that the form says to apologize distinguished by mode and components.

Key words: form, speech act, apology, Javanese speech community
\end{abstract}

\section{PENDAHULUAN}

Permintaan maaf lazimnya dilakukan seseorang jika melakukan kesalahan. Pada masyarakat tutur bahasa Jawa, meminta maaf cenderung dinyatakan terlebih dahulu meskipun sebenarnya hal yang dituturkan atau dilakukannya belum tentu salah. Salah satu bentuk TT dalam interaksi sosial adalah TT meminta maaf (selanjutnya TTMM). Dalam TTMMbeberapa halperlu dipertimbangkan oleh $\mathrm{N}$, di antaranya: (1) identitas sosial budaya para partisipan ( $\mathrm{N}$ dan T), (2) topik tuturan, dan (3) konteks situasi. Selain itu, yang perlu dipertimbangkan dalam melakukan TT adalah prinsip kesantunan bertutur (principles of politeness)yang berlaku di dalam suatu masyarakat tutur. Untuk itu, dalam penelitian ini dibahas secara mendalam 
berbagai strategi TTMM dalam bahasa Jawa di wilayah Kota Surabaya. Surabaya merupakan kota multietnis yang kaya budaya. Beragam etnis ada di Surabaya, seperti etnis Melayu, Cina, India, Arab, dan Eropa. Etnis Nusantara pun dapat dijumpai, seperti Madura, Sunda, Batak, Kalimantan, Bali, Sulawesi yang membaur dengan penduduk asli Surabaya membentuk pluralisme budaya yang selanjutnya menjadi ciri khas kota Surabaya.

Fokus penelitian ini adalah bentuk tindak tutur meminta maaf pada masyarakat Jawa di wilayah Kelurahan Beringin, Kecamatan Lakarsantri, Kota Surabaya. Berdasarkan permasalahan itu, tujuan penelitian ini adalah untuk menemukan dan memerikan bentuk tindak tutur meminta maaf dalam bahasa Jawa pada masyarakat Jawa di wilayah Kelurahan Beringin, Kecamatan Lakarsantri, Kota Surabaya.

Menurut Ibrahim (1993:16), yang mengembangkan teori dari Austin, TTMM termasuk pada kategori tindak ilokusi komunikatif sub-kategori acknowledgments. Meminta maaf (apologizing) mengekspresikan penyesalan karena telah melukai atau mengganggu mitra tutur. Menurut klasifikasi Searle (1979:16), TTMM termasuk dalam kategori tindak ilokusi ekspresif, yaitu fungsi ilokusi yang mengungkap atau mengutarakan sikap psikologis Pn terhadap keadaan yang tersirat dalam ilokusi. Berdasarkan penggolongan Leech (1983:76), TTMM termasuk dalam kategori Berdasarkan penggolongan tersebut, TTMM termasuk dalam kategori tindak tutur ilokusi subkategori ekspresif.

Dari sudut pandang komunikasi antarpribadi, TTMM (apologizing) menempatkan peran utamanya pada Pn (Lubis, 1993). Dengan demikian, 'beban' untuk bersantun bahasa lebih bertumpu pada Pn, karena ia harus menjaga perasaan Pt. Dengan kata lain, karena Pn berharap keinginannya berupa permohonan maaf dianggap sebagai sebuah wujud kesantunan berbahasa (dan berperilaku secara umum), ia akan berusaha untuk 'membujuk' (atau bisa juga 'memaksa') Pt agar mau menerima permohonan maafnya sebagai bentuk tanggung jawab sosial untuk menjaga keharmonisan komunikasi.

\section{LANDASAN TEORI}

Menurut Brown dan Levinson (1987:187) ada dua strategi dalam tindak tutur yang santun, yaitu secara: (1) bald on record (terbuka) dan (2) off record (terselubung). Strategi pertama terbagi dalam dua jenis kesantunan, yaitu (1) terbuka dengan kesantunan positif dan (2) terbuka dengan kesantunan negatif. Strategi terbuka dengan kesantunan positif mempunyai 15 substrategi, yaitu (1) menarik perhatian Pt, Pn menguraikan beberapa hal untuk menarik perhatian Pt sebelum ia meminta maaf, (2) melebih-lebihkan tuturan, Pn membuat pernyataan yang berlebih yang menghasilkan efek baik untuk Pt (3) 
mengintensifkan kesenangan Pt, Pn bisa saja melakukaknnya dengan memuji Pt sehingga Pt menjadi senang barulah ia meminta maaf, (4) menggunakan pemarkah identitas kelompok, dalam hal ini adalah kelompok masyarakat Jawa khususnya wilayah Surabaya yang memunyai bentuk sapaan yang khas, (5) meminta pendapat $\mathrm{Pt}$, meminta maaf dengan mempertimbangkan pendapat-pendapat dari Pt, (6) menghindari ketidaksetujuan dengan mengungkapkan pernyataan yang tidak disetujui oleh Pt, (7) memberikan prosouposisi, yaitu dengan menyuguhkan praanggapan-praanggapan yang dapat ditafsirkan oleh $\mathrm{Pt}$, (8) bergurau, Pn meminta maaf dengan bergurau, dalam hal ini adalah dengan lelucon berupa pantun atau parikan yang khas di daerah Surabaya, (9) menegaskan keinginan Pt, Pn menyebutkan keinginan-keinginan Pt yang tidak bisa ia penuhi, maka dari itu ia meminta maaf, (10) berjanji untuk tidak mengulangi kesalahan merupakan strategi yang tepat untuk meminta maaf, (11) dengan beroptimis, Pn meminta maaf kepada Pt, Pn optimis kalau permintamaafannya diterima oleh Pt, (12) dengan melibatkan Pt dalam pertuturan dapat mengurangi konflik-konflik antara Pn dan Pt, (13) memberikan alasan, Pn mengungkapkan beberapa alasan mengapa ia bisa melakukan kesalahan, (14) dengan resiprokal, baik Pn maupun Pt akhirnya bisa saling memahami kesalahan dan kekurangan masing-masing, dan (15) dengan memberi hadiah, Pn memberi hadiah kepada Pt untuk mendukung permintamaafannya.

Strategi terbuka dengan kesantunan negatif mempunyai 10 substrategi, yaitu (1) pernyataan tidak langsung yang konvensional, (2) bertanya, permintaan maaf diwujudkan dalam kalimat tanya, (3) berpesimis, Pn berpesimis terlebih dahulu untuk menarik belas kasihan Pt, (4) meminimalkan kerugian Pt, Pn berusaha menyatakan hal-hal untuk menebus kesalahannya sehingga bisa menguntungkan $\mathrm{Pt}$, (5) memberikan penghormatan, Pn meminta maaf kepada Pt dengan segala kerendahhatian dan bisa dilakukan dengan memanggil Pt dengan panggilan yang lebih hormat, (6) Pn langsung meminta maaf kepada Pt, (7) Pn maupun Pt mengimpersonalkan diri, hal ini bertujuan supaya kedua belah pihak tidak saling menyalahkan dan akhirnya bisa saling memaafkan, (8) menyatakan peran keduanya secara umum sehingga baik Pn mauppun Pt mau menyadari kesalahan masingmasing, (9) dengan nominalisasi, Pn berharap kalau kesalahannya dianggap sebuah barang yang berukuran kecil sehingga menjadi tidak diperhitungkan lagi oleh Pt, dan (10) dengan melakukan percakapan mendalam untuk saling memahami dan memaafkan satu sama lain.

Untuk strategi yang kedua, yaitu off record (terselubung), memiliki 15 substrategi, yaitu (1) dengan memberikan isyarat, Pn memberikan isyarat kepada Pt untuk permintamaafannya, (2) memberikan petunjuk, Pn menggunakan petunjuk-petunjuk 
tertentu untuk meminta maaf, biasanya menggunakan tanda-tanda yang sudah dikenal secara umum, (3) memberikan presuposisi, Pn memberikan kemungkinan-kemungkinan yang bisa ditafsirkan oleh $\mathrm{Pt}$, (4) mengurangi pernyataan, dengan tidak mengatakan hal yang seutuhnya, Pn meminta maaf kepada Pt, (5) menambah pernyataan, merupakan lawan dari pernyataan kurang, Pn menggunakan kalimat-kalimat yang panjang dan terkesan tidak perlu untuk diucapkan saat meminta maaf, (6) menggunakan tautologi, Pn menggunakan tautan-tautan sebagai alasan saat meminta maaf, (7) menggunakan kontradiksi, Pn menyatakan hal yang berlawanan untuk meminta maaf kepada Pt, (8) ironi, Pn menggunakan sindiran-sindiran untuk mengakui dan meminta maaf, (9) metafora, Pn menggunakan perbandingan untuk mengungkapkan kesalahannya, (10) pertanyaan retorik, Pn menggunakan pertanyaan retorik yang sebenarnya tidak perlu dijawab oleh Pt, (11) ambiguitas, Pn menggunakan kalimat yang rancu, sehingga Pt harus menafsirkannya sendiri, (12) dengan samar-samar, Pn meminta maaf dengan tidak langsung mengungkapkan kata maaf kepada Pt, (13) overgeneralisasi, yaitu dengan mengungkapkan semua hal itu sama, jika semua orang pernah salah maka ia juga begitu, (14) mengganti Pt, Pn tidak menyebutkan Pt dengan langsung tetapi diganti dengan hal lain namun tetap merujuk pada Pt, dan (15) elipsis, Pn menggunakan Tt yang elips atau tidak lengkap untuk meminta maaf kepada Pt.

Yule (1996:113) menggunakan strategi yang berisikan ungkapan-ungkapan permintaan maaf karena suatu pembebanan. Dengan perilaku kesantunan yang menggunakan kalimat lebih terperinci, kadang-kadang juga diperpanjang kalimatnya, dan sering kali diikuti dengan rasa keragu-raguan. Strategi itu menentukan berhasil atau tidaknya suatu tindakan meminta maaf. Chaer (2010:97) menyebutkan ada tiga macam strategi yang digunakan dalam tindak tutur meminta maaf dalam bahasa Indonesia, yakni diikuti kata-kata fatis, kata interjektif, dan menggunakan kata-kata sapaan. Berbeda dengan itu, Yanti (2001:7) menyebutkan tiga cara tindak tutur minta maaf, yaitu (1) tindak tutur meminta maaf langsung yang dilontarkan tanpa basa-basi yang terbagi lagi atas dua jenis, yaitu (a) langsung dengan kesantunan positif dan (b) langsung dengan kesantunan negatif; (2) tindak tutur maaf yang tidak dilontarkan, tetapi dapat diketahui secara tersirat; dan (3) hanya diam saja (tanpa ujaran).

Berdasarkan ulasan para ahli di atas, strategi yang dipilih penutur dalam melakukan tindak meminta maaf sangatlah beragam. Dalam penelitian ini, semua strategi dianggap benar dan layak untuk dipilih. Data lapanganlah yang akan menentukan hasil penelitian ini, strategi apa dan strategi yang bagaimana yang dipilih oleh penutur dalam meminta maaf. 
Strategi penyampaian tindak tutur meminta maaf lebih ditekankan pada pihak $\mathrm{N}$, yang berupaya agar permintaan maafnya diterima oleh T. Secara garis besar, strategi TTMM dapat diklasifikasikan berdasarkan dua hal, yaitu (1) cara dan (2) mediasi. Berdasarkan cara, strategi TTMM dibedakan menjadi cara terbuka dan terselubung. Berdasarkan mediasi, TTMM dibedakan menjadi TTMM langsung dan TTMM tidak langsung. Hasil pertautan dari kedua dasar tersebut, maka strategi TTMM terdiri atas empat strategi, yaitu (1) terbuka langsung, (2) terbuka tidak langsung, (3) terselubung langsung, dan (4) terselubung tidak langsung.

\section{PEMBAHASAN}

Strategi penyampaian TTMM lebih ditekankan pada pihak Pn, yang berupaya agar permintaan maafnya diterima oleh Pt. Secara garis besar, strategi TTMM dapat diklasifikasikan berdasarkan dua hal, yaitu (1) cara dan (2) mediasi. Berdasarkan cara, strategi TTMM dibedakan menjadi cara blaka 'terbuka' (bald on record) dan samudana 'terselubung' (off record). Berdasarkan perantara, TTMM dibedakan menjadi TTMM langsung dan TTMM tidak langsung. Dalam tulisan ini hanya akan dibahas TTMM cara pertama yaitu dengan cara samudana 'terselubung' (off record).

Penyampaian TTMM secara samudana 'terselubung' (off record), yaitu dengan menyampaikan permintaan maaf secara samar-samar (Adipitoyo: 2007). Strategi secara terselubung ini juga mengacu pada empat jenis prinsip kerja sama (PK) menurut Grice (1975) dan juga maksim kesantunan menurut Leech (1983). Strategi Pn dalam meminta maaf bisa saja mematuhi maksim-maksim tersebut, atau bahkan melanggar salah satu atau lebih. Strategi TTMM berdasarkan kasus yang diberikan oleh Brown dan Levinson (1987:95) dapat diklasifikasikan lagi berdasarkan jenis mediasinya, yaitu: (1) secara terselubung langsung dan (2) secara terselubung dengan tidak langsung.

\section{Terselubung Langsung}

Penyampaian TTMM secara samudana langsung 'terselubung langsung', yaitu dengan menyampaikan permintaan maaf secara samar-samar yang dilakukan oleh orang yang bersalah (Pn) langsung kepada orang yang dirugikan $(\mathrm{Pt})$ tanpa perantara (mediasi). Berdasarkan data yang diperoleh di lapangan, strategi TTMM secara terselubung langsung dapat diklasifikasi menjadi 11 substrategi sebagaimana yang dikemukakan oleh Brown dan Levinson (1987:102).

Substrategi terselubung langsung tersebut di antaranya (1) menggunakan gurauan atau lelucon, (2) memahami keinginan T, (3) berpesimis, (4) meminimalkan kerugian T, (5) 
menunjukkan keengganan, (6) memperbanyak alasan, (7) memberikan isyarat, (8) menggunakan ujaran yang tidak lengkap, (9) menggunakan petunjuk asosiasi, (10) mengurangi pernyataan (understaters), dan (11) menggunakan tautologi. Secara berurutan akan dipaparkan sebagai berikut (Wedhawati, 2006).

\section{a. Menggunakan Gurauan atau Lelucon}

Lelucon atau gurauan ini merupakan hal yang pada dasarnya memiliki pengetahuan yang sama baik Pn maupun Pt. Lelucon sebenarnya dapat digunakan untuk mempertegas pernyataan permintaan maaf, sehingga TTMM mudah didengar dan dicerna oleh Pt. Masyarakat Surabaya sudah sangat terbiasa dengan adanya gurauan yang berupa parikan. Parikan ini biasanya digunakan dalam akhir pertemuan, baik resmi maupun tidak resmi.

(1) Konteks: Penjual pangsit (OmRo) melakukan kesalahan terhadap Erin yang memesan pangsit tanpa kecap dan caos.

Erin : Lo om, kok athik kecap mbek caos?

'Lo Om, kok pakai kecap dan saos?'

OmRo: Adhuh, pecut dijeplakna, nek kebacut dikapakna. (St.Ts.1)

Erin : Wadhuh pelanggaran Cak, terpaksa iki!

OmRo: Takganti ta?

Erin : Nggak-nggak, nggak usah om.

Dalam peristiwa di atas, saat OmRo diprotes Erin karena pangsit pesanannya tidak sesuai. Sebelumnya, Erin telah memesan pangsit tanpa kecap dan caos, namun pada akhirnya Omro tetap menambahkan kecap dan caos di pangsitnya. Menyadari kelalaiannya, dengan reflek, Omro membuat parikan untuk mengakui kelalaiannya dan juga untuk meminta maaf kepada Erin. OmRo di sini memang dikenal dengan sosok yang lucu, dalam gerobak pangsitnya saja penuh dengan simbol-simbol Suroboyoan. Maka pantas saja kalau ia meminta maaf dengan menggunakan parikan. Walau berat menerima kesalahan om OmRo, namun Erni tetap menerima pangsit itu dan memaafkan kelalaiannya OmRo, karena Erni berpikir sudah terlanjur dibuatkan, kalau tidak mau menerima maka OmRo akan rugi.

Strategi OmRo dalam meminta maaf ini sebenarnya telah melanggar maksim cara, yaitu OmRo telah mengatakan susuatu yang tidak ringkas, malah terkesan diperpanjang. Dengan adanya sampiran dalam parikan (pantun), hal itu jelas melanggar maksim cara atau juga maksim kuantitas. Namun demikian, hal itu tidak dipermasalahkan oleh Pt, karena Pt jadi merasa terhibur oleh parikan Pn. Dalam hal ini, Pn telah menaati maksim pertimbangan (Gunarwan, 2006:166), yaitu dengan memaksimalkan rasa senang Pt. 


\section{b. Memahami Keinginan Pt}

Salah satu strategi untuk meminta maaf adalah dengan mengintensifkan percakapan yang menunjukkan bahwa Pn benar-benar memahami dan mengetahui keinginan Pt. Hal ini bisa dilakukan dengan menceritakan hal-hal kecil yang menunjukkan keinginan Pt.

(2) Madi: Lah apa ta No koen iku adoh-adoh mergawe tutuk

Kalimantan barang?

'Kenapa sih No kamu itu jauh-jauh bekerja sampai Kalimantan segala?'

Nono: Aku ngerti Cak karepe sampeyan, sampeyan pengene aku sing ngramut Pake-Buke, tapi yak apa maneh, ancene pangane neng luwar pulau. (St.Ts.2) Sampeyan ae sing ngramut Pake-Buke, sing cedhek.

'Saya tau Mas maumu, maunya saya kan yang merawat Bapak Ibu, tapi mau gimana lagi, memang nafkahku di luar pulau. Anda saja yang merawat Bapak Ibu.'

Konteks pertuturan di atas adalah sesaat sebelum Nono berangkat ke Samarinda untuk bekerja, dan berpamitan kepada kakaknya (Madi) yang rumahnya bersebelahan dengan orang tuanya. Sebelum meminta maaf, Nono sebelumnya menyebutkan dengan jelas bahwa ia sebenarnya mengetahui apa keinginan Pt. Dengan menyebutkan apa yang diinginkan, sebenarnya Nono telah menaati maksim kesetujuan, yaitu dengan memaksimalkan kesetujuan dengan Pt. Barulah ia meminta maaf. Hal ini nampak jika data tersebut diubah menjadi seperti di bawah ini.

(52a) Nono: Aku ngerti Cak karepe sampeyan, sampeyan pengene aku sing ngramut Pake-Buke, tapi yak apa maneh, ancene pangane neng luwar pulau. Sepurane. (St.Ts.2a) Sampeyan ae sing ngramut Pake-Buke, sing cedhek.

Namun, setelah meminta maaf, Pn justru melanggar maksim kearifan, yaitu dengan mengatakan sesuatu yang tidak meminimalkan kerugian $\mathrm{Pt}$, namun justru menambah rugi Pt. Dengan menyuruh Pt untuk melakukan sesuatu yang awalnya diharapkan agar Pn lah yang melakukannya, namun justru kini Pt lah yang harus melakukannya.

Data lain yang menggunakan strategi memahami keinginan Pt adalah saat Mami menjenguk Enda yang sakit. Sebagai teman Pt, Pn mengetahui keinginan Pt, namun karena Pn tidak dapat memenuhi keinginan tersebut, maka Pn meminta maaf.

(3) Mami: Ki brownis senenganmu. Aku ngerti nek senenganmu brownis coklat, ning merga ora enek, iki takgawakne sing pandan. Ora apa-apa ta? (St.Ts.3)

'Ini Brownis kesukaanmu. Aku tahu kalau kesukaanmu rasa brownis coklat, tetapi karena tidak ada, ini takbawakan rasa pandan. Tidak apa-apa kan?

Jika dieksplisitkan, maka TTMM di atas akan berubah menjadi: 
(53a) Mami: Ki brownis senenganmu. Aku ngerti nek senenganmu brownis coklat, ning merga ora enek, iki takgawakne sing pandan. Sepurane. (St.Ts.3a)

\section{c. Berpesimis}

Dalam strategi ini, Pn mengeksplisitkan ekspresi tuturannya dengan mengungkapkan kondisi yang minim. Misalnya dengan melontarkan sesuatu untuk menjelekkan diri sendiri, sehingga kesalahan Pn terasa besar, dan sulit untuk dimaafkan oleh Pt. Datanya dapat dicermati sebagai berikut.

(4) Kasa : Pak Wano, piye kabare Fuzi saiki?

'Pak Wano, bagaimana keadaan Fuzi?'

Wano: Aku wingi emosi tenan Pak ndelokke Fuzi sirahe metu getihe wokeh. Sakik emosie, pagere malih koyok ngono (sambil menunjukkan muka sedih dan menyesal). Piye-piye a ya wis kebacut, aku sing salah Pak. (St.Ts.4)

'Saya kemarin sangat emosi Pak melihat kepalanya Fuzi keluar darah. Bagaimanapun juga sudah terlanjur, saya yang salah Pak.

Kasa : Halah, ora apa-apa Pak, penting Fuzi saiki wis sehat. 'Halah, tidak apa-apa, penting Fuzi sudah sehat.'

Konteks situasi pertuturan di atas adalah saat siang hari, Fuzi anak dari Wano sedang bermain di dekat pagar rumah Kasa. Tiba-tiba pagar rubuh dan menimpa Fuzi sampai kepelanya bersimbah darah. Mengetahui itu, Wano langsung menolong anaknya dan membawanya pulang. Setelah itu, Wano mengambil cangkul lalu merusak pagar yang telah menimpa anaknya itu. Sore harinya, Kasa berkunjung ke rumah tetangganya itu untuk menanyakan kabar Fuzi.

Tt Wano yang pertama menunjukkan bahwa ia ingin menceritakan hal yang sebenarnya terjadi. Namun, hal tersebut sebenarnya tidaklah ditanyakan oleh Kasa. Hal tersebut tentu saja telah melanggar PKS Grice. Dari maksim kuantitas, Tt Wano itu telah melanggar submaksim yang pertama, yaitu Wano telah menyatakan sesuatu yang tidak informatif seperti yang diperlukan Im. Im hanya memerlukan jawaban yang menyatakan keadaan Fuzi saat ini, namun Wano tidak memberikan hal tersebut. Dari segi maksim relevansi, jawaban Wano tersebut jelas telah melanggarnya, yaitu dengan mengatakan sesuatu yang tidak ada relevansinya dengan pertanyaan Kasa.

Berdasarkan prinsip kesantunan Leech, Tt Wano di atas telah mematuhi maksim kerendahhatian, yaitu dengan memaksimalkan penjelekan kepada diri. Dengan menyatakan kalau sedang emosi, menunjukkan bahwa Pn tengah menjelakkan dirinya sendiri di depan Pt. Hal itu dilanjutkan dengan bentuk pematuhan atas maksim simpati, yaitu dengan 
memaksimalkan ungkapan simpati kepada Pt. Dengan menyebutkan kalau kepala anaknya mengeluarkan banyak darah, hal itu dimaksudkan untuk menarik rasa simpatik dari Pt.

Selain itu, Tt tersebut juga menyatakan rasa pesimistis Pn atas pengakuan kesalahannya itu, selain tidak bisa membuat pagar Kasa kembali bagus, Wano juga siap menerima penolakan dari Kasa atas permintaan maafnya. Jika penanda pesimistis itu dihilangkan dan diganti dengan kata maaf secara langsung, maka Tt Wano akan menjadi

(54a) Wano: Piye-piye a ya wis kebacut, aku sing salah Pak. Sepurane.

(St.Ts.4a)

'Saya kemarin sangat emosi Pak melihat kepalanya Fuzi keluar darah. Bagaimanapun juga sudah terlanjur, saya yang salah Pak. Maaf.

\section{d. Meminimalkan Kerugian Pt}

Dalam maksim kearifan menurut Leech, Pn harus meminimalkan keuntungannya dan memaksimalkan keuntungan Pt. Dalam meminta maaf, Pn berusaha meminimalisir kerugian Pt walaupun tidak begitu memaksimalkan keuntungan Pt. Hal ini nampak pada data saat Erin menanyakan pembayaran air ke Yita. Seminggu sebelumnya Erin sudah menitipkan uang air ke Yita. Hal ini merupakan kebiasaan Erin untuk menitipkan uang tagihan air karena Erin selalu tidak ada di rumah saat penarik tagihan datang.

(5) Erin: Buk, aire pun ditarik?

'Bu, airnya sudah ditarik?'

Yita: Anu e Mbak, pas bapakke narik rene, aku kae pas metu, dadine ya ora ketemu, tapi mene neng bapake Rara arep dibayarne neng kantore langsung. (St.Ts.5)

'Anu e Mbak, pas bapaknya yang narik ke sini, saya pas keluar rumah, jadinya tidak ketemu. Tapi besok sama bapaknya Rara akan dibayarkan ke kantor pusat.

Erin: Kula nitip sekaliyan mboten napa-napa nggih bu? (St.Ts.6)

'Saya nitip sekalian ndak pa-pa ya bu?'

Yita: Ora pa-pa Mbak, wong kuwi ya merga salahku kok..

'Tidak apa-apa Mbak, orang itu juga salah saya kok.'

Sebelum menuturkan permintaan maafnya secara langsung, Yita terlebih dahulu menjelaskan mengapa airnya belum dibayarkan. Untuk menebus kesalahannya itu, dengan mengatakan kalau suaminya (bapake Rara) akan membayarkan tagihan air ke kantornya langsung. Hal itu tentu merupakan wujud kepatuhan Pn terhadap maksim kearifan, yaitu dengan memaksimalkan keuntungan bagi Pt. Dengan membayarkan langsung ke kantor pusat, hal itu merupakan suatu keuntungan bagi Erin karena tidak perlu repot-repot membayar tagihan air ke kantor pusat. 
Selain itu, Tt Yita tersebut juga merupakan bentuk kepatuhan atas maksim kedermawanan, yaitu dengan memaksimalkan biaya bagi Pn. Dengan membayarkan tagihan air Erin ke kantor pusat (walau itu tidak murni hanya membayarkan tagihan Erin, tetapi juga membayar untuk tagihannya sendiri), hal itu tentunya akan menambah beban $\mathrm{N}$ (khususnya adalah suami Yita yang harus membayar ke kantor pusat). Namun begitulah wujud permintaan maaf Yita atas kesalahannya terhadap Erin, yaitu dengan meminimalisir kerugian Erin dan berusaha memaksimalkan keuntungan bagi Erin.

Dalam peristiwa Tt di atas, selain Yita yang meminta maaf, Erin juga telah melakukan hal yang sama. Dengan meminta tolong kepada Yita untuk membayarkan tagihan air, Erin secara terselubung telah meminta maaf kepada Yita. Hal itu disebabkan Erin merasa juga telah merepotkan Yita. Penenda utama untuk pemakluman Erin adalah frase mboten napanapa. Jika frase tersebut dihilangkan, maka Tt Erin hanya merupakan Tt imperatif biasa tanpa ada maksud untuk meminta maaf seperti di bawah ini.

(55a) Erin: Kula nitip sekaliyan nggih bu? (St.Ts.6a)

'Saya nitip sekalian ya bu?'

e. Menunjukkan Keengganan

Dalam strategi ini, Pn dapat berusaha untuk menunjukkan bahwa ia sebenarnya enggan untuk melakukan kesalahan, namun Pn tetap melakukannya, untuk itu maka Pn meminta maaf. Hal itu dapat dilihat dalam data (St.Ts.2) seperti di muka.

(6) Madi: Lah apa ta No koen iku adoh-adoh mergawe tutuk

Kalimantan barang?

'Kenapa sih No kamu itu jauh-jauh bekerja sampai Kalimantan segala?'

Nono: Aku ngerti Cak karepe sampeyan, sampeyan pengene aku sing ngramut Pake-Buke, tapi yak apa maneh, ancene pangane neng luwar pulau. (St.Ts.7) Sampeyan ae sing ngramut Pake-Buke, sing cedhek.

'Saya tau Mas maumu, maunya saya kan yang merawat Bapak Ibu, tapi mau gimana lagi, memang nafkahku di luar pulau. Anda saja yang merawat Bapak Ibu.'

Sebelum meminta maaf, Nono menyatakan keengganannya untuk meninggalkan kampung halamannya. Hal ini ditunjukkan dengan pernyataan tapi yak apa maneh. Kata tapi menunjukkan keengganan akan sesuatu hal, dan dilanjutkan lagi dengan yak apa maneh yang menunjukkan kalau hal itu memang harus dipilih dan dilakukan. Dan karena sesuatu yang terpaksa itulah, akhirnya Pn meminta maaf kepada Pt. Berdasarkan prinsip kesantunan, hal tersebut merupakan bentuk ketaatan Pn atas maksim kesetujuan. Dengan menunjukkan keengganan, sebenarnya Pn ingin memaksimalkan kesetujuannya dengan Pt. Walau kata maaf 
tidak terucap, namun kata maaf itu sebenarnya bisa diletakkan di bagian akhir, sehingga $\mathrm{Tt}$ tersebut menjadi:

(56a) Nono: Aku ngerti Cak karepe sampeyan, sampeyan pengene aku sing ngramut Pake-Buke, tapi yak apa maneh, ancene pangane neng luwar pulau. Sepurane. (St.Ts.7a) Sampeyan ae sing ngramut Pake-Buke, sing cedhek.

\section{f. Memperbanyak Alasan}

Strategi meminta maaf yang paling umum adalah dengan memberikan alasan. Jika semakin banyak memberikan alasan, maka akan semakin bersimpati pula Pt terhadap Pn. Alasan yang dimaksud adalah alasan yang benar-benar di luar kendali atau kapasitas Pn sehingga ia melakukan kesalahan. Data TTMM berikut ini terjadi saat Siki menyapa Awan di suatu pagi. Malam sebelumnya ada acara tahlilan di rumah Pak Agus, tetapi Pak Awan tidak dapat hadir. Ia-pun meminta maaf kepada Siki walau yang punya acara bukanlah dia.

(7) Siki: Mau bengi kok ora ketok neng tahlilan nggone Pak Agus Cak?

'Tadi malam kok tidak kelihatan di tahlilan rumah Pak Agus?'

Awan: Sewengi untuku cekot-cekot, awak ya gak enak Cak, watuk pileg, kemriyang, gek udan pisan. (St.Ts.8) Diparanana aku gak isok teka Cak. Dadi yak apa maneh.

'Semalam gigiku linu, juga tidak enak badan Pak, batuk, pilek, panas dingin, terus hujan juga. Dijemputpun saya juga tidak bisa datang Pak. Jadi, ya mau gimana lagi.

Bentuk permintaan maaf Awan tersebut nampak dari banyaknya alasan yang diutarakannya. Mulai dari keadaan giginya yang sakit, batuk, flu, demam, dan diperparah dengan cuaca yang buruk. Dari prinsip kerja sama, alasan yang sengaja diperbanyak oleh Pn ini telah melanggar maksim kuantitas, yang dinyatakan Pn telah melebihi apa yang diperlukan $\mathrm{Pt}$, dan hal itu malah menjadikannya sebagai sesuatu yang berlebihan. Mengatakan sesuatu yang berlebihan juga telah melanggar maksim cara. Kendati telah melanggar beberapa maksim dalam PKS, namun dalam PK, alasan yang diperbanyak itu telah mematuhi maksim simpati. Dengan menuturkan alasan yang banyak, Pn telah memaksimalkan ungkapan untuk menarik simpati Pt. Dengan begitu, Pn berharap Pt akan memaklumi ketidakhadirannya.

Berdasarkan uraian alasan yang dituturkan oleh Awan selaku Pn, maka kata maaf sebenarnya bisa saja dituturkan secara lokusif. Sehingga pola strategi untuk meminta maaf adalah dengan kata maaf dulu baru alasan, sehingga Tt tersebut menjadi

(57a) Awan: Sepurane, sewengi untuku cekot-cekot, awak ya gak enak Cak, watuk pileg, kemriyang, gek udan pisan. Diparanana aku gak isok teka Cak. Dadi yak apa maneh. 
atau alasan dulu baru meminta maaf seperti berikut.

(57b) Awan: Sewengi untuku cekot-cekot, awak ya gak enak Cak, watuk pileg, kemriyang, gek udan pisan. Diparanana aku gak isok teka Cak. Dadi yak apa maneh. Sepurane.

\section{g. Memberikan Isyarat}

Jika Pn mengatakan sesuatu secara implisit, itu artinya Pt harus menginterpretasikan sesuatu yang mungkin ada hubungannya dengan tuturan Pn tersebut. Hal itu tentunya melanggar maksim relevansi. Dalam hal ini, Pn mengatakan suatu tuturan yang tidak ada kata sepura 'maaf', namun maksud sebenarnya adalah untuk meminta maaf. Permintamaafan itulah yang diberikan isyarat.

(8) Enda: Iki aku wis neng bakul jus kulon prapatan. Kowe sida rene ta?

'Ini saya sudah di warung jus barat perempatan. Kamu jadi ke sini kan?

Mura: Wadhuh, aku ora isa. Maeng janjine ora neng kono kok, ki aku wis tekan Wiyung. Nek neng kunu aku ora isa. (St.Ts.8)

'Waduh, aku tidak bisa. Tadi janjinya tidak di situ, ini aku sudah sampai Wiyung. Kalau di situ aku tidak bisa datang.'

Enda: Yaaaah......

Konteks pertuturan di atas terjadi saat Enda sedang menunggu Mura untuk bertemu di sebuah warung. Enda lalu meng-sms Mura, dan ternyata ia tidak bisa datang. Dalam percakapan sms tersebut, pernyataan Mura bahwa dia tidak bisa datang karena sudah jauh dari tempat yang ditentukan Enda, sebenarnya ia telah meminta maaf secara tersamar. Mura mengisyaratkan kalau posisinya sudah jauh dari tempat Enda, untuk itu ia tidak dapat mendatanginya. Pemberitahuan posisi tersebutlah yang menjadi isyarat akan ketidakbisaan Mura, sekaligus meminta pemakluman dari Enda.

Jika pernyataan maafnya tidak disamarkan, maka Tt Mura adalah:

(St.Ts.8a) Wadhuh, sepurane, aku ora isa. Maeng janjine ora neng kono kok, ki aku wis tekan Wiyung. Nek neng kunu aku ora isa, sepurane.

'Waduh, maaf, aku tidak bisa. Tadi janjinya tidak di situ, ini aku sudah sampai Wiyung. Kalau di situ aku tidak bisa datang.'

Berdasarkan data di atas, walau tidak ada kata maaf secara langsung, namun Enda tetap bisa memahami dan juga memaklumi Mura. Walau Enda juga sedikit kecewa, namun Enda tetap bisa menerima ketidakhadiran Mura. 
h. Menggunakan Ujaran yang Tidak Lengkap

Penggunaan bentuk yang tidak lengkap merupakan salah satu strategi untuk meminta maaf secara terselubung. Dengan tidak meneruskan tuturannya, Pt sudah bisa memahami apa maksud yang akan diungkapkan oleh Pn. Adapun datanya seperti di bawah ini.

(9) Enda: Pak, mie goreng setunggal.

'Pak, mie goreng satu'

Bapa: kaya biyasane Mbak?

'Seperti biasa Mbak?'

Enda: ok..

Setelah menunggu, pesenannya pun jadi.

Bapa: Ki Mbak sega-e...

'Ini Mbak nasinya..'

Enda: Loh, kok sega Pak? Aku kan pesen mie goreng?

'Loh, kok nasi Pak? Saya kan pesan mie goreng?'

Bapa: Looooo, biyasane lak sega sih Mbak? Wis kadhung takgawekne sega kaya biyasae ki Mbak. Ya ... (St.Ts.9)

'Lo, biasanya kan nasi Mbak? Sudah terlanjur takbuatkan nasi seperti biasanya Mbak. Ya...

Enda: Wadhuh, nggih pun Pak niku mawon...

'Waduh, ya sudah Pak itu saja.'

Sebenarnya dalam peristiwa tutur di atas telah terjadi pertuturan yang gagal. Saat Enda sedang membeli nasi goreng di warung langganannya, Bapa kurang begitu memperhatikan pesanan Enda dan pertanyaannya kaya biyasane yang dijawab ok oleh Enda langsung mengingatkan Bapa kalau Enda biasa memesan nasi goreng. Setelah mengetahui kalau ternyata yang dibuatkan tidak sesuai dengan pesanan Enda, Bapa tetap merasa benar karena dalam pikirannya masih pesanan biasanya adalah nasi goreng dan itu telah disetujui oleh Enda. karena sudah terlanjur dibuat, untuk mengakhiri kesalahpahaman tersebut, Bapa belum sempat meminta maaf.

Hal itu dilakukan Bapa dengan sengaja menghentikan tuturannya. Jika tuturannya Bapa diteruskan, maka akan menjadi:

(St.Ts.9a) Looooo, biyasane lak sega sih Mbak?Wis kadhung takgawekne sega kaya biyasae ki Mbak. Ya, sepurane Mbak.

'Lo, biasanya kan nasi Mbak? Sudah terlanjur takbuatkan nasi seperti biasanya Mbak. Ya maaf Mbak..'

Walau kalimat itu tidak terlontarkan, dan hanya berhenti sampai Ya..., namun Pt tetap bisa menangkap maksud dari Pn tersebut. Hal itu dapat dilihat dari respons Pt yang tetap menerima pesanannya walau dengan agak keberatan. Penerimaan ini juga merupakan bentuk pemaafan Enda atas kesalahan Bapa. 


\section{i. Menggunakan Petunjuk Asosiasi}

Strategi penggunaan petunjuk asosiasi digunakan jika Pn menyebut sesuatu yang diasosiasikan dengan tindak yang dikehendaki Pn untuk dilakukan oleh Pt. Sejalan dengan pendapat Brown dan Levinson (1989:215), strategi penggunaan petunjuk asosiasi dapat berupa penggunaan petunjuk asosiasi yang terkait dengan pengetahuan bersama antara Pn dan Pt, hal itu tampak pada peristiwa saat Rara tidak sengaja menginjak kaki Ilha. Data percakapannya adalah sebagai berikut.

(10) Rara: Adhuh, Ha, gak pa-pa kan?

'Aduh, Ha, tidak apa-apa kan?'

Ilha : Gak pa-pa piye, lara ki..

'Tidak ada apa-apa gimana, sakit nih...'

Rara: Pisss...Piss! (St.Ts.10) (Sambil mengangkat tangan kanan dengan menegakkan jari telunjuk dan jari tengah)

Kata pisss (dalam bahasa Inggris adalah peace yang berarti damai) yang diucapkan sambil mengangkat jari telunjuk dan jari tengah merupakan suatu asosiasi yang telah diketahui bersama, baik oleh Pn maupun oleh Pt. Asosiasi dari tuturan yang disertai tindakan tersebut berarti wujud permintaan maaf dari Pn kepada Pt. Tanpa mengucapkan kata maaf, maka Pt sudah tahu kalau maksud Pn adalah untuk meminta maaf. Namun asosiasi tersebut tidak semua orang paham dan mengerti, mungkin hanya dikenal pada kalagana tertentu saja, misalnya anak-anak muda atau bisa juga orang tua yang bisa berbahasa Inggris sehingga tau arti dari kata piss.

\section{j. Mengurangi Pernyataan (understaters)}

Dalam strategi pernyataan kurang (understatement), Pn telah melanggar maksim kuantitas. Dalam strategi pernyataan kurang, Pt mendapat tugas untuk menginterpretasikan tujuan ilokusi Pn dengan cara memahami bahwa Pn melakukan pelanggaran maksim kuantitas. Menurut Brown dan Levinson (1987:217), strategi pernyataan kurang direalisasikan dengan cara menyatakan kurang dari apa yang dikehendaki.

(11) Mawi: We ki dijaluki tulung ngunu ae ora isa, padhahal mung barang sepele ae. Lek aku isa budhal dhewe, gak bakalan aku njaluk tulung kowe.

'Kamu itu dimintai tolong begitu saja tidak bisa, padahal itu hal sepele saja. Kalau saya bisa berangkat sendiri, tidak akan saya menyuruh kamu.'

Suto: astaga. (St.Ts.11)

Mawi: (diam) 
Konteks percakapan di atas adalah sesaat sebelum itu, Mawi meminta tolong sesuatu kepada Suto. Namun Suto tidak berhasil menolong Mawi, padahal ia sudah berusaha. Dan Mawi pun marah kepada Suto. Keduanya merupakan teman akrab. Omelan Mawi dirasa cukup menyakitkan oleh Suto. Jawaban dari Suto yang hanya sepatah kata, itupun bukan yang diharapkan oleh Mawi jelas telah melanggar maksim kuantitas dan cara dalam PKS. Suto tidak menyatakan sesuatu seperti yang diperlukan oleh Mawi, Mawi sebenarnya memerlukan kata maaf langsung dari Suto, namun hal itu tidak terucap. Jawaban astaga dari Suto juga sangat ambigu, apakah Suto ingin meminta maaf pada Mawi atau malah justru ingin memarahi balik Mawi.

Jawaban yang singkat itu sebenarnya juga mengandung maksud tertentu menurut PK, yaitu untuk meminimalkan ketidaksetujuan dengan Pt dan akhirnya bisa meminimalkan rasa tidak senang Pt. Dengan tidak mengungkapkan hal yang sebenarnya terjadi (mungkin pembelaan), Suto berusaha untuk tidak membuat Mawi menjadi lebih marah lagi. Selain itu juga, hal tersebut dilakukan untuk meminimalkan rasa tidak senang Pt atas Pn, jika tuturan Pn itu dilanjutkan, maka sama saja Pn telah membuat Pt tidak senang dengan alasan yang diungkapkan. Maka dari itu, untuk menghindari hal-hal yang lebih buruk lagi, maka Pn lebih memilih untuk meng-understate tuturannya.

\section{k. Menggunakan Tautologi}

Pada strategi tautologi nampaknya Pn memberikan informasi kepada Pt, namun informasi yang diberikan itu tidak hanya bersifat informatif, tetapi juga bersifat apologis, yaitu untuk meminta maaf ataupun sekadar pemakluman. Seperti dinyatakan Brown dan Levinson (1989:220), Pn yang meminta maaf dengan strategi tautologis pada dasarnya menganjurkan Pt untuk mencari interpretasi informatif pada Tt yang tidak informatif, seperti tampak dalam data berikut.

(12) Wuri: Piye Bu acarae Dina wingi? Rame ta gak?

'Bagaimana Bu acaranya Dina kemarin? Rame tidak?'

Suti: Rame pol Bu. Nggone Asa wis taktitipne Tati wingi. 'rame banget Bu. Punyanya Asa sudah saya titipkan tati kemarin.'

Wuri: Iya, wingi. Susah aku Mbak mbek Asa, angel eram maeme. (St.Ts.12) Dadine ora mari-mari larane.

'Ya begitulah. Susah saya dengan Asa, susah sekali makannya. Jadinya tidak sembuh-sembuh sakitnya.'

Suti: Ya ngunu kuwi Bu arek cilik lek wis lara, susah. Aku sampek gurung ngongak blas, repot dhewe neng ngomah..hehe

'Ya begitulah $\mathrm{Bu}$ anak-anak kalau sudah sakit, susah. Aku juga belum sempat menjenguk, repot di rumah sendiri.' 
Tt Wuri yang merupakan kalimat tautologis adalah Susah aku Mbak mbek Asa, angel eram maeme. Kalimat tersebut sebenarnya tidak semata-mata untuk menginformasikan keadaan anaknya, namun hal yang lebih penting adalah Pn sedang mengemukakan alasan mengapa ia tidak bisa hadir dalam acaranya Suti. Hal itu merupakan bentuk permintaan maaf yang disamarkan, dengan membuat tautan cerita yang bisa digunakan sebagai alasan dari kesalahan.

Berdasarkan PKS Grice, apa yang diungkapkan Wuri merupakan pernyataan yang tidak jelas dan ambigu sehingga dapat menimbulkan kerugian bagi Pt, yaitu Pt harus mengeluarkan biaya (berpikir), yaitu untuk menginterpretasikan informasi tersebut sebagai bentuk permintaan maaf. Namun, dari sudut pandang PK, Tt Wuri tersebut tepat digunakan untuk menarik simpati dari Pt. Dengan menceritakan keadaan anaknya yang sedang sakit, Pn telah berusaha untuk menarik dan memaksimalkan simpati dari Pt. Dengan begitu, Pt akan bersimpati dan mau memaklumi serta memaafkan Pn.

\section{Terselubung Tidak Langsung}

Penyampaian TTMM secara samudana ora langsung 'terselubung tidak langsung', yaitu dengan menyampaikan permintaan maaf secara samar-samar yang dilakukan oleh orang yang tidak bersalah $(\mathrm{Pn})$ kepada orang yang dirugikan $(\mathrm{Pt})$. Kedudukan Pn di sini hanya sebagai perantara (mediasi). Berdasarkan data yang diperoleh di lapangan, strategi TTMM secara terselubung tidak langsung dapat diklasifikasi menjadi 4 substrategi sebagaimana yang dikemukakan oleh Brown dan Levinson (1987:102). Substrategi terselubung tidak langsung tersebut di antaranya (a) memberikan hadiah, (b) menggunakan $\mathrm{Tt}$ imperatif, (c) menggunakan tautologi, dan (d) menggunakan Tt metafor. Secara berurutan akan dipaparkan sebagai berikut.

\section{a. Memberi Hadiah}

Strategi yang paling nyata untuk meminta maaf adalah dengan menyenangkan wajah serta hati Pt yaitu dengan memberikan dia hadiah yang sesuai dengan keinginannya. Walaupun strategi terkesan kuno, namun efeknya sangatlah nyata. Hadiah yang diberikan tidak harus berupa barang, tetapi bentuk hubungan sosial seperti rasa simpati, saling pengertian, dan juga kerjasama.

Data berikut diperoleh saat Enda akan memberi les privat ke Geri. Tepat pukul 15.00 Enda tiba di rumah Lin, tapi rumah Lin masih terkunci, Enda pun menunggu di luar. Beberapa lama kemudian Lin datang dan terjadilan pertuturan berikut. 
'Mari masuk Mbak!'

Enda: Ndak pa-pa bu.. (lalu mereka masuk rumah bersama-sama. Setelah Enda duduk di kursi, Geri datang dari dalam dengan membawa sebuah gantungan kunci)

Geri: Ini kak en, dari tante Ila. (St.Ts.13)

Ila: (dari dalam muncul sebentar, sambil senyum). Mau wis nunggu suwe ya?

Tadi sudah menunggu lama ya?'

Enda: Oh, gak pa-pa, suwun ya gantungan kuncine.

'Oh, tidak apa-apa. Terimakasih ya gantungan kuncinya.'

Dalam peristiwa tutur tersebut, yang menjadi Pn adalah Ila. Ila merasa bersalah kepada Enda, karena telah membuat Enda menunggu. Hal itu dilakukan dengan pemberian gantungan kunci kepada Enda, sembari bertanya Mau wis nunggu suwe ya? Pertanyaan ini sebenarnya merupakan bentuk permintaan maaf Ila kepada Enda, dan untuk meminta maaf itulah Ila memberi Enda sebuah hadiah berupa gantungan kunci. Hal ini pun direspons oleh Enda. pertanyaan Ila tersebut merupakan pertanyaan tertutup, di mana jawabannya hanya ada dua, iya atau tidak. Tapi, karena Enda mengetahui maksud Ila yang sebenarnya, maka Enda pun menjawab oh, ndak pa-pa. Jawaban ini menyiratkan kalau Enda telah menerima permintaan maaf dari Ila, dan malah berterimakasih atas hadiah yang diberikan. Adapun jika Tt itu berupa TTMM lokusif menjadi berikut.

(63a) Ila: (dari dalam muncul sebentar, sambil senyum). Mau wis nunggu suwe ya? Sepurane.

Tadi sudah menunggu lama ya? Maaf.'

b. Menggunakan Tt Imperatif

Strategi terselubung tidak langsung ini dilakukan oleh orang yang dekat dengan subjek yang bersalah. Orang meminta maaf lazimnya menggunakan kalimat permintaan yang halus supaya permintaan-maafnya diterima. Namun, ada kalanya permintaan maaf dilakukan dengan modus imperatif, yaitu menyuruh.

(14) Atia: Sing sabar ae ya Mbak! (St.Ts.14) (sambil menepuk pundak En). Aja kapok lo ya! Arek-arek iku ancene mbuh kok, tambah gedhe tambah mokong.

'Yang sabar aja ya Mbak! Jangan kapok lo ya! Anak-anak itu memang kok, tambah besar tambah nakal.'

Enda: Iya bu, ndak pa-pa. Sudah terbiasa...hehehe

Tt Atia kepada Enda adalah menyuruh Enda untuk bersabar dalam menghadapi dan mengajari anak-anaknya. Maksud sabar di sini adalah sabar untuk menghadapi kenakalan anak-anak Tn saat belajar bersama Enda. Menyadari kesalahan anak-anaknya saat belajar 
itulah, Atia meminta maaf kepada Enda, yaitu dengan cara menyuruh Enda untuk tetap bersabar dan meminta agar Enda tidak kapok mengajari anak-anaknya. Hal ini juga dikuatkan dengan gerakan tepukan tangan Atia ke Enda. Tt Atia selanjutnya kembali menegaskan akan kesalahan anak-anaknya, yang semakin hari semakin nakal.

Dengan demikian, posisi Atia di sini adalah sebagai media atau perantara dari anakanaknya yang telah melakukan kesalahan saat belajar bersama Enda. Mengetahui hal tersebut, Enda juga menerima keadaan dan permintaan maaf Atia dengan terbuka, malah diimbangi dengan senyuman, karena Enda juga menyadari bahwa sikap anak-anak memang begitu dan Enda juga sudah terbiasa menghadapi anak-anak yang nakal.

Dilihat dari PKS, strategi ini jelas telah melanggar maksim cara. Pn telah menggunakan pernyataan ambigu. Dengan menyuruh untuk bersabar, padahal ia sebenarnya mau meminta maaf atas kenakalan anak-anaknya. Namun dari segi PK, strategi ini telah mematuhi maksim kerendahhatian, yaitu Pn telah memaksimalkan penjelekan kepada diri (anak-anaknya Pn). Selain itu juga dengan memilih kata sabar, maka Pn sebenarnya telah memuji Pt, yaitu secara terselubung mengatakan kalau Pt itu orang yang sabar (Sudaryanto, 1991).

\section{c. Melakukan Percakapan Mendalam}

Salah satu strategi terselubung tidak langsung adalah dengan melakukan percakapan secara mendalam. Dalam percakapan ini nampaknya Pn memberikan informasi kepada Pt, namun informasi yang diberikan itu tidak hanya bersifat informatif, tetapi juga bersifat apologis, yaitu untuk meminta maaf ataupun sekadar pemakluman. Seperti dinyatakan Brown dan Levinson (1989:220), Pn yang meminta maaf dengan strategi ini pada dasarnya menganjurkan Pt untuk mencari interpretasi informatif pada Tt yang tidak informatif, seperti tampak dalam data berikut. Strategi meminta maaf secara terbuka langsung dengan kesantunan negatif yang terakhir adalah dengan melakukan percakapan secara mendalam. Datanya seperti dalam percakapan yang diperoleh saat Enda mau mengajari Ero membaca, namun Ero tidak mau belajar dan malah marah-marah disertai menangis.

(15) Ero : (nangis dan teriak-teriak tidak mau belajar)

Enda: Nunggu mama ae ya?

Ero : Mok! 'Tidak!'

Rula: Ero nggih ngaten niku. Riyin pas umur tigang taun, Ero kejang, mari iku dokter memvonis nek perkembangane Ero mablik dadi bayi umur setatun maneh. Dadine nek saiki umure pitung taun, nanging asline kaya bayi umur limang taun. Nanging bapak-ibuke tetep nyekolahne Ero neng SD. (St.Ts.15)

'Ero ya seperti itu. Dulu waktu usia tiga tahun, Ero kejang, setelah itu dokter memvonis kalau perkembangan Ero kembali menjadi bayi berusia satu tahun. Jadinya, kalau sekarang dia berusia tujuh 
tahun, namun aslinya masih 5 tahun. Namun, orangtuanya tetap menyekolahkan di SD.'

Enda: Ow, ngaten ta Pak. Kok mamae mboten crita teng kula nggih?

'Ow. Begitu ya Pak. Kok mamanya tidak cerita pada saya ya?'

Rula: La kuwi Mbak, wong tuwane tetep nganggep Ero ki kaya bocah normal. Neng buktine ya sakelas gurung isok maca dhewe, mangkakne terus dilesne. Ampun dilebokne ati. (St.Ts.15)

' $\mathrm{Na}$ itu Mbak, orangtuanya tetap menganggap Ero itu anak berusia normal, tapi buktinya ya dia sendiri yang belum bisa membaca dalam satu kelas, makanya dileskan ke Mbak. Jangan dimasukkan hati ya Mbak!

Enda: Owalah, ngaten ta Pak. Inggih mboten napa-napa Pak. Mengke dangu-dangu lak nggih pun biyasa.

'Ow, jadi begitu ya Pak. Iya, tidak apa-apa Pak. Lama-lama nanti juga terbiasa.'

Rula: Ya muga-muga ae mbak.

'Ya, semoga saja Mbak.'

Percakapan mendalam tersebut merupakan salah satu strategi permintaan maaf yang disamarkan, dengan membuat tautan cerita yang bisa digunakan sebagai alasan (fakta) dari kesalahan. Berdasarkan PKS Grice, apa yang diungkapkan Rula merupakan pernyataan yang tidak jelas dan ambigu sehingga dapat menimbulkan kerugian bagi Pt, yaitu Pt harus mengeluarkan biaya (berpikir), yaitu untuk menginterpretasikan informasi tersebut sebagai bentuk permintaan maaf. Namun, dari sudut pandang PK, Tt Rula tersebut tepat digunakan untuk menarik simpati dari Pt. Dengan menceritakan keadaan cucunya yang mengalami perkembangan kurang normal, Pn telah berusaha untuk menarik dan memaksimalkan simpati dari Pt. Dengan begitu, Pt akan bersimpati dan mau memaklumi serta memaafkan Pn.

\section{d. Menggunakan Tt Metafor}

Strategi metaforis pada dasarnya hampir sama dengan strategi ironi, yaitu sama-sama melanggar maksim kualitas. Hanya saja, dalam strategi metaforis, Pn menjadikan lambang tertentu sebagai bahan komparasi. Hal itu sejalan dengan pernyataan Brown dan Levinson (1989:222) bahwa dengan berstrategi metaforis, Pn telah melakukan pelanggaran maksim kualitas secara lebih mendalam. Misalnya saja dalam $\mathrm{Tt}$ berikut yang membandingkan manusia biasa dengan manusia sekelas nabi. Konteks data ini sama dengan pada percakapan nomor (21) di muka.

(16) Nasi: Saukurane nabi ae rak ya nduwe salah ta Cak-cak, apa maneh aku sing menungsa biasa ngene. (St.Ts.16)

'Seorang nabi saja bisa melakukan kesalahan, apalagi saya yang hanya manusia biasa.'

Maru: Ya ancene ngunu Cak. Aku ya dudu nabi Cak, aku ya nduweni salah mbek pean. 
'Ya memang begitu Pak. Saya juga bukan nabi, saya juga mempunyai salah ke Anda.'

Pernyataan Nasi yang membandingkan dirinya dengan nabi merupakan bentuk metafora untuk menyelamatkan mukanya dari keterancaman. Hal itu juga merupakan strategi Ns untuk meminta maaf secara tidak langsung kepada Maru. Menyadari hal itu, Maru mersepons dengan menyatakan hal yang sama, yang pada intinya semua manusia biasa pastilah punya salah.

Pernyataan Nasi tersebut dari PKS jelas telah melanggar maksim cara, yaitu Nasi telah menyatakan sesuatu dengan tidak jelas serta penuh ambiguitas, yang merugikan Maru karena harus menyimpulkan sendiri maksud dari Tt Nasi tersebut. Di balik pelanggarannya atas maksim cara dan kearifan, namun sebenarnya Nasi telah mematuhi maksim kerendahhatian, yaitu memaksimalkan penjelekan terhadap diri sendiri. Nasi telah menyadari kalau dirinya bukanlah nabi, sehingga wajar kalau punya banyak salah. Namun demikian, pelanggaran PKS dan pematuhan PK tersebut hanya merupakan strategi Nasi untuk meminta maaf, dan efeknya adalah Maru bisa memaklumi dan malah balik meminta maaf walaupun juga secara tidak langsung diungkapkan.

\section{SIMPULAN}

Strategi TTMM yang dapat dianalisis dengan mudah hanyalah strategi TTMM yang memiliki penanda leksikon berupa kata atau frase sepurane 'maaf' dan sinonimnya. Sedangkan TTMM yang tidak memiliki penanda leksikon sepurane 'maaf', maka harus dianalisis dengan cara analisis yang lebih kritis dan mendalam. Analisis ini berdasarkan pada konteks tuturan serta respons dari Pt saat Pn menuturkan permintamaafannya yang secara implisit. Dalam hal ini TTMM digolongkan pada TTMM strategi samudana 'terselubung'. Berdasarkan strategi terselubung, strategi TTMM dapat diklasifikasi menjadi 2, yaitu strategi samudana 'terselubung' langsung dan strategi samudana 'terselubung' tidak langsung. Yang termasuk dalam TTMM samudana 'terselubung' secara langsung, yakni (a) menggunakan gurauan atau lelucon, (b) memahami keinginan pt, (c) berpesimis, (d) meminimalkan kerugian pt, (e) menunjukkan keengganan, (f) memperbanyak alasan, (g) memberikan isyarat, (h) menggunakan ujaran yang tidak lengkap, (i) menggunakan petunjuk asosiasi, (j) mengurangi pernyataan (understaters), dan (k) menggunakan tautologi. Sedangkan TTMM yang terselubung tidak langsung, di antaranya (a) memberi hadiah, (b) menggunakan Tt imperatif, (c) melakukan percakapan mendalam, dan (d) menggunakan Tt metafor. 


\section{DAFTAR PUSTAKA}

Adipitoyo, Sugeng, dkk. (2007). "Orang Jawa Sub-Etnis Surabaya" makalah Seminar Pendidikan dan Kebudayaan, Biro Mental-Spiritual Pemerintah Provinsi Jawa Timur, 56 September 2007

Brown, Penelope dan C. Levinson. (1987). Politeness: Some Universal in Language Usage. Cambridge: Cambridge University Press.

Chaer, Abdul. (2010). Kesantunan Berbahasa. Jakarta: Rineka Cipta.

Grice, H. P. (1975). Logic and Conversation. Dalam P. Cole \& J. L. Morgan (Eds). Syintaz and Semantics Volume 3 Speech Act. New York: Academic Press.

Leech, Geoffrey. (1983). Principles of Pragmatics. London: Longman.

Lubis, A. Hamid Hasan. (1993). Jenggala Bahasa Indonesia. Cetakan ke (angka terakhir). Bandung: Angkasa.

Sudaryanto et al. (Penyunting). (1991). Tata Bahasa Baku Bahasa Jawa. Cetakan ke-1. Yogyakarta: Duta Wacana University Press.

Wedhawati et al. (2006). Tata Bahasa Jawa Mutakhir. Edisi Revisi. Cetakan ke 1 - 5. Yogyakarta: Kanisius.

Yanti, Yusrita. (2001). "Tindak Tutur Maaf dalam Bahasa Indonesia di Kalangan Penutur Minangkabau" dalam Linguistik Indonesia tahun ke-19 No. 1:93-104.

Yule, George. (1996). Pragmatik (Terjemahan Indah Fajar Wahyuni). Yogyakarta: Pustaka Pelajar. 